\title{
Rationalizing manufacturing work station: a case study
}

\section{- Le Ngoc Quynh Lam}

University of Technology, VNU-HCM

\section{ABSTRACT:}

Small and medium size enterprises often encounter problems in managing and operating production system effectively and efficiently, which result in losing their competitive advantages. It is, therefore, essential to suggest applicable methods to solve these problems completely and inexpensively. Purposely, an application of work design and standardization process to rationalize manufacturing work station would be proposed. A case study at a furniture company is presented as an example. It aims to create a scientific workstation with standardized operations to help worker get more comfortable, and increase productivity, quality and safety. An implementation of proposed method at a workstation of a furniture company brings promising results. A new workstation is redesigned more effectively in terms of comfortableness, safety, and the productivity increasing $15 \%$.

Keywords: Rationalizing, furniture manufacturing, work station, work design, standardization process, lean workstations.

\section{INTRODUCTION}

An effective and efficient work station would bring many advantages for any competitive company. Principles of a good work station have been broken into three basic subdivisions: (1) the use of the human body; (2) the arrangement and conditions of the workplace; (3) the design of tools and equipments [1]. They could be achieved if good standardized work and workplace were designed.

Standardized work is one of the most powerful lean tool and known as baseline for kaizen or continuous improvement. Actually, principles of motion economy can be understood better than merely being accepted as memorized rules. Standardizing the work adds discipline to the culture, which would bring many benefits such as documentation of the current process for all shifts, reductions in variability, easier training of new operators, reductions in injuries and strain, and baseline for improvement activities [2]. Principles of motion economy are now also called the principles of and guidelines for work design.

Work design is the basic for how work is conceived in broad terms, translated across organizational levels, and structured for the units and the individuals performing the work. It is tightly woven into the structure and function of organizations [3]. The goal of work design is to create a work system that is productive and efficient and to fit the human operator.

Work design and standardized work is important for a range of individual, group, and organizational outcomes [4]. Despite the intense interest in and importance of work design, research into the measurement of job and work characteristics has been narrow, incomplete, and problematic [5]. Therefore, an integration of work design and standardization process in a systematically way is required.

The importance of work system design is underscored by any organization dependence on human efforts to accomplish its goals [6]. In recent years, furniture and wood products 
become one of major export products of Viet Nam (according to General Statistics Office of Vietnam, 2012). However, it is almost based on manual works and unfortunately there has been not officially research to design good manual work systems only following worker or manager experience.

Therefore, a work design and standardization process would be suggested in following section. A clear and standard process to achieve a quality work station would be designed. An application on a furniture manufacturing case would be mentioned to illustrate the suggested method. In addition, experience on implementing a research on a real system would be presented. Finally, some conclusions and suggestions would be concluded.

\section{APPLICABLE WORK DESIGN AND STANDARDIZATION PROCESS}

Work design intends to create a productive and efficient work system, which involves specifying the content and methods of work or job. It should be carried out by experienced personal with the necessary training and background, consistent with the goals of the organization, in written form and understood and agreed to by both management and employees [6]. Expected results of work design and standardization process are work standards. They could be used to establish reasonable productivity targets for experienced workers, provide productivity goals for training purposes, eliminate wastes, make processes more consistent, reduce variability, and improve quality.

In order to create an effective work station, many factors have to be considered such as workspace layout, work instructions, task analysis, human factors, workload analysis, environmental parameters, safety analysis and also cost analysis. It is really a complex process, so an applicable and standard one is required in step by step.

A work design and standardization process is suggested in systematic and applicable way through 6 steps as followings:

\section{Step 1: Identity work stations of the studied system}

It is firstly required and initial information for any work design and standardization research.
An estimation of scope or scale of work and research boundary would be identified. System should be separated into suitable functional areas, and then work stations of each area are easier determined. The basic information of each work station should include name of workstation, picture, machine or equipment, relative function, and workers.

\section{Step 2: Determine required tasks at each work station}

Job or work at each workstation concentrates on some aspects of product (or part) or service. It is divided into small increments called tasks to result in efficient operations due to highly repetitive tasks.

\section{Step 3: Design a work guideline instruction for work stations}

There are different methods to do the same job and also task at a workstation, so standardization is required as a work guideline instruction. Motion study, the systematic study of the human motions used to perform an operation, is done. It could help eliminate unnecessary motions, combine activities, reduce fatigue, improve the arrangement of workplace as well as improve the design of tools and equipment.

\section{Step 4: Identify elements of each work station}

At each workstation, all relative elements need to be determined. They have close relations with required tasks to complete a job at the workplace. Existing arrangement is basis information for the next step.

\section{Step 5: Rearrangement workstation elements or redesign them if necessary}

A good workplace is expected as a result based on rearrangement of workstation elements or redesign them if necessary. Equipment, tool, working table, chair, carrying tool table and also working place could be changed or designed to new ones. If any change was done, a work guideline instruction (Step 3) should be redesigned.

Human factors should be considered as important factors to design work place. When the workstation around the human body is built up, for example, a maximum reachable range of available worker(s) should be mentioned. As a result, the workplace layout plays a large role in 
simplifying the workstation and improving the efficiency of workers.

\section{Step 6: Implementation \& correction if necessary}

A plan for implementation of a work guideline instruction and redesigned workplace should be done clearly and officially. The relative worker working at studied workplace has to be trained to adapt new working method with working place and also tools or equipment. An evaluation on efficiency of new design should be done to prove that the research gets good results and relative worker or manager should follow.

\section{A CASE STUDY}

Almost enterprises in furniture manufacturing industry in Vietnam are small and medium sized companies, and strongly depend on worker skills and efforts. Most works are done based on experience rather than a scientific process. As a result, productivity and product quality is usually low with high variability, so it is hard to manage. In addition, work place layout is allocated based on operator experience. It, hence, commonly results in inappropriate workspace.

Work sheet table, a discipline, for each workstation is essential in this case based on its promising benefits as mentioned in previous section. In order to implement operations as in standardized table, equipments, tools and even workstation could be rearranged or redesigned if necessary.

As an illustration, a research was done at a cutting workstation, and then an implementation of a proposed process mentioned in section 2 is described in detail as followings.

\section{Step 1: Identity work stations of the studied system}

In this example, cutting workstation is examined. Its area is defined as $2 \mathrm{~m} \times 3 \mathrm{~m}$, and designed for one worker operating cutting machine, as shown on Figure 1. Function of this workstation is to cut materials into different sizes as requirements.

\section{Step 2: Determine required tasks}

In this step, required operations to accomplish a task at this station have to be specified. While doing this step, problems related to operations can be determined. It is highly recommended to record and observe operations at the workstation from different directions at different times for different products or parts. At this step, the determined problems have to be stated and they are bases for proposing improvement solutions.

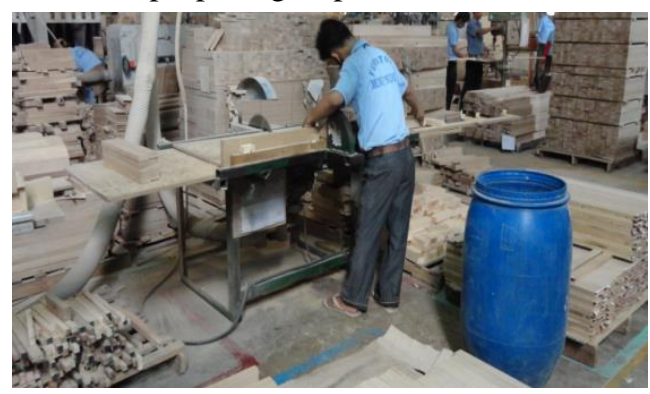

Figure 1. Current workstation

For instance, the activity to throw redundant materials was inappropriate (see Figure 2), so the repeating rotations resulted in tiredness and productivity reduction. Therefore, this activity should be examined carefully and redundant operations could be eliminated.

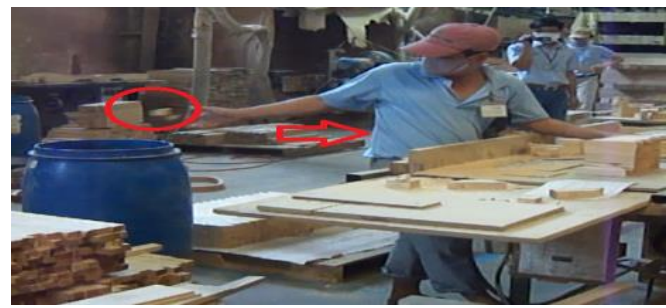

Figure 2. Throwing unnecessary

Based on observation on the practice and recorded video, it was found that some activites were not standardized. When processing a batch of parts/products, each item was processed in different ways. As an illustration on Figure 3, the worker picked workpieces in different manner and quantity. Similarly, workpieces were not put in the cutting table in the same way, as on Figure 4 , in which workpieces are put in different manner. The question was which way better is. Besides, work-in-process (WIP) was not scientificcially arranged, so WIPs were stacked over the shoulder of worker (see Figure 5), which caused an obstruction and unsafety.

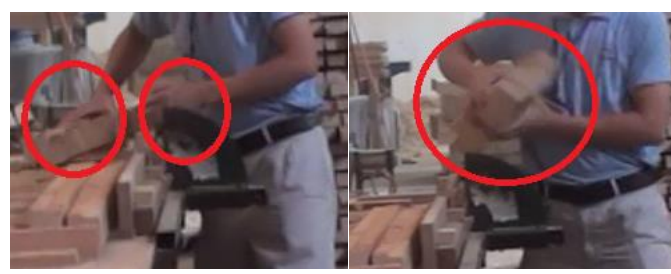

Figure 3. Work piece picking-up activity 


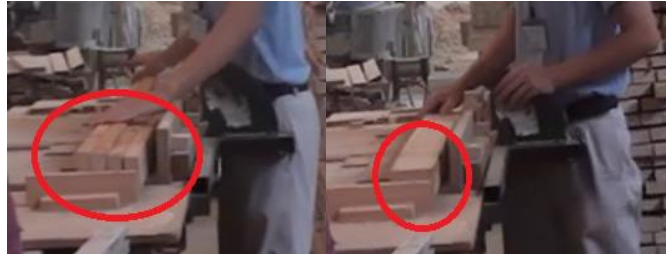

Figure 4. Work piece arrangement on cutting table

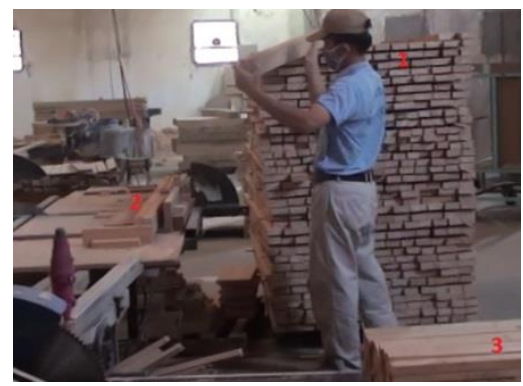

\section{Step 3: Design a work discipline}

Based on this version, we can examined how a task should be done accurately in terms of it is comfortable for worker to perform the task effectively and efficiently, and follows human factors standards. A standard work table is illustrated as on Figure 6.

In addition, improvement activities were proposed. For instances, rules for picking up work pieces were suggested as on Figure 7.

Figure 5. High stacked WIPs

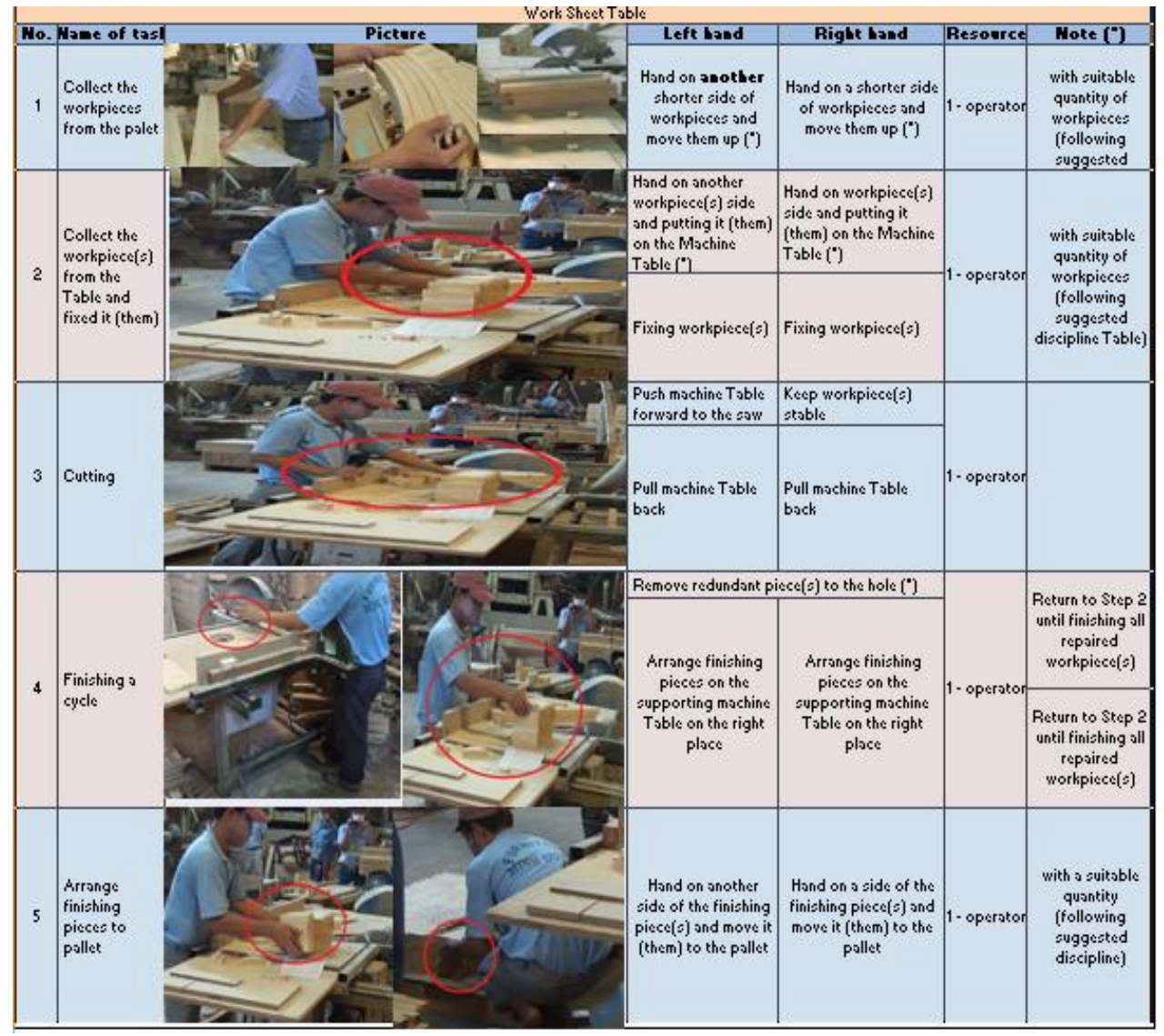

Figure 6. Standard work table 


\begin{tabular}{|c|c|c|}
\hline \multicolumn{3}{|c|}{ RULE FOR PICKING WORKPIECES } \\
\hline * Plank: & & 1 plank/time \\
\hline \multicolumn{3}{|l|}{ * Bar: } \\
\hline \multicolumn{2}{|c|}{ - Length >1200mm } & 2 bars/time \\
\hline \multicolumn{3}{|c|}{ - Length $\leq 1200 \mathrm{~mm}$, follows below table } \\
\hline & & Width $(\mathrm{mm})$ \\
\hline Thickness $(\mathrm{mm})$ & $<60$ & $60-120$ \\
\hline$<13$ & 20 & 10 \\
\hline $13-24$ & 10 & 5 \\
\hline $25-60$ & 4 & 2 \\
\hline$>60$ & - & 1 \\
\hline
\end{tabular}

Figure 7. Rules for picking work piece

\section{Step 4: Identify elements of work station}

In addition, some other ideas for improvement that results in the rearrangement or redesign of workspace are also defined.

In order to rearrange workstation effectively and efficiently and conformity with standard work table, components and its position at workstation were defined as shown on Figure 8. Some inappropriate positions were realized such as position 1 and 5. These locations should be rearranged to allow worker moving clockwise and more comfortable.

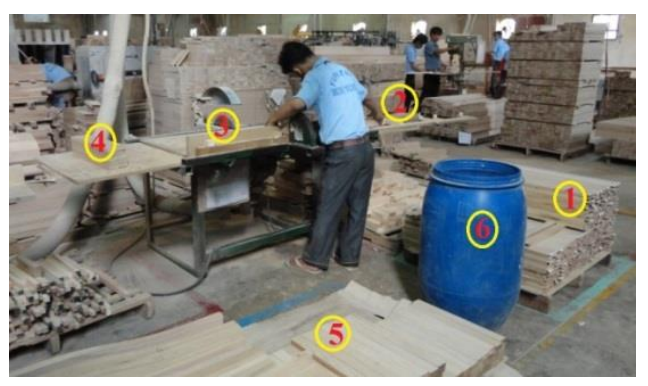

\section{Step 5: Rearrange elements of workstation or/and redesign them if necessary}

A study on activity that throws redundant materials results in a rearrangement of location 6 (see Figure 9). For improvement, it is essential to remove part that is not belong to or serve for the workstation, and component 6 would be reallocated by redesigning the cutting table so that recycle bin is embed as on Figure 10.

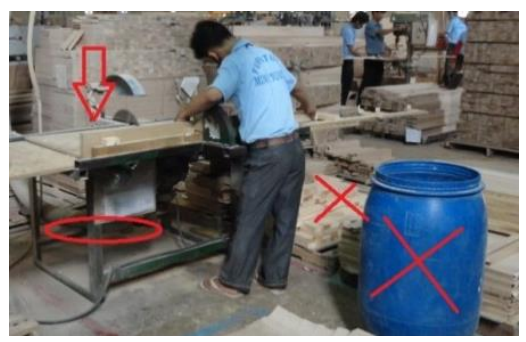

Figure 9. Workstation rearrangement

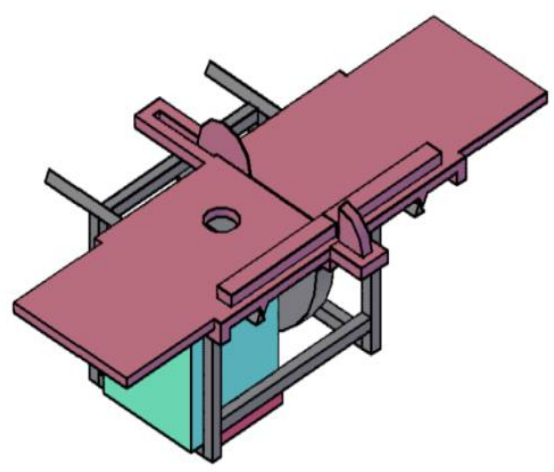

Figure 10. New cutting table

Finally, the workstation was redesigned with an integration of elements as on Figure 11.

Figure 8. Numbering the workstation components

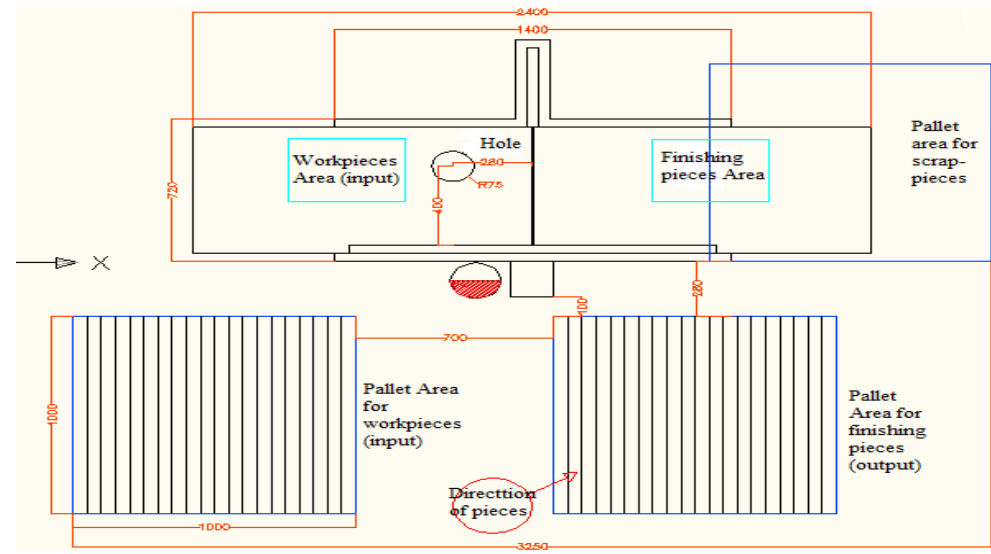

Figure 11. Design of workstation 


\section{Step 6: Implementation \& correction if} necessary

New design of workstation should be examined carefully before implementation in terms of technical feasibility, efficiency, as well as comfortable. Besides, during the implementation process, we should monitor to assure that it would be done correctly as design. During this phase, other improvement, if found, should be done also. The workstation was then implemented as on Figure 12.

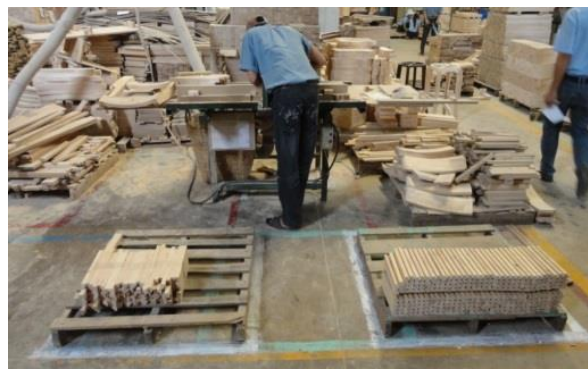

Figure 12. New workstation

The new workstation is highly applicable due to criteria such as more comfortable, productivity (improve about 15\%, according to company's manager), and also satisfying the technical requirements of the workstation. As a result, the proposed workstation has been applied for more than 30 workstations in the whole company system.

\section{CONCLUSIONS}

Work design and standardization process is really an interesting work, which brings many benefits for enterprises with many small and inexpensive improvements, according to lean philosophy. This paper is written based on results obtained from a real lean project which is currently implemented at a furniture company.

Based on practical results, proposed method could be promisingly applicable for the furniture industry in Vietnam. Although furniture has its own characteristics, this study is also applicable for other industries with some modifications.

In the system perspective, this paper only mentioned about the study for one workstation in a complex manufacturing system with many workstations. In order to optimize whole system, it is essential to optimize workstations systematically and synchronously, which would bring new challenges that converts the current system into a lean production system.

\title{
Hợp lý hóa trạm sản xuất: một trường hợp nghiên cứu
}

\section{- Lê Ngọc Quỳnh Lam}

\author{
Trường Đại Học Bách Khoa, ĐHQG - HCM
}

\section{TÓM TÁT:}

Các doanh nghiệp vừa và nhỏ thường gặp những vấn đề khó khăn trong quản lý và vận hành hiệu quả quá trình sản xuất dẫn đến mất thế mạnh cạnh tranh. Vấn đề đặt ra là cần có những giải pháp giải quyết được vấn đề trên một cách triệt để mà không tốn kém chi phí đầu tư và dễ dàng áp dụng, triển khai. Bài báo này trình bày phương pháp hợp lý hóa trạm làm việc bằng cách áp dụng phương pháp thiết kế và chuẩn hóa công việc. Đây là một công cụ của sản xuất tinh gọn; phương pháp thông qua việc phân tích công việc, chuẩn hóa thao tác, và thiết kế, sắp xếp lại trạm làm việc giúp cho công nhân làm việc thuận tiện, hiệu quả hơn, giúp nâng cao năng suất, đảm bảo chất lượng và an toàn trong sản xuất. Theo đó, bài báo trình bày những giới thiệu chung trong 
phần 1; phương pháp thiết kế và chuẩn hóa công việc hiệu quả được trình bày trong phần 2, và phần 3 mô tả chi tiết các bước áp dụng và triển khai phương pháp đề xuất trong phần 2, cuối cùng là kết luận và kiến nghị. Kết quả áp dụng

Từ khóa: Hợp lý hóa trạm làm việc, thiết kế công việc, chuẩn hóa công việc, trạm làm việc tinh gọn

\section{REFERENCES}

[1]. Niebel B. E., and Freivalds A., Methods, standards, and work design, McGraw-Hill, Singapore, International Editions, (1999).

[2]. Womack J., and Jones D., Lean thinking, Simon \& Schuster, the $2^{\text {nd }}$ Edition, (1996).

[3]. Torraco R.J., Work design theory: a review and critique with implications for human resource development, Human resource development, Quaterly, John Wiley \& Sons, Vol.16, no.1, (2005).

[4]. Morgeson F.P., Delaney-Klinger K. A., and Hemingway M. A., The importance of job autonomy, cognitive ability, and job-related phương pháp cho thấy trạm làm việc được bố trí hiệu quả hơn, công nhân làm việc thuận tiện, an toàn, và năng suất tăng lên $15 \%$ trong khi chí phí đầu tư không đáng kể. skill for predicting role breadth and job performance, Journal of Applied Psychology, Vol.90.

[5]. Morgeson F. P. and Humphrey S. E., The work design questionnaire (WDQ): Developing and validating a comprehensive measure for assessing job design and the nature of work, Journal of Applied Psychology, Vol.91, no.6, 1321-1339.

[6]. Stevenson W. J., Operations management, $9^{\text {th }}$ Edition, McGraw-Hill/Irwin, New York, (2007) 